\title{
POETIC LINE AND MUSICAL STRUCTURE IN THE 13TH-CENTURY MOTET
}

\author{
Marie Louise MARTíNEZ-GÖLLNER
}

\begin{abstract}
The examination of early two-voice motets reveals the prominence of the seven- (or eight-) syllable line in the poems. When declaimed in the usual manner, i.e. syllabically, in either the first or second rhythmic mode, this verse conforms to a time frame of two double Longs (or two modern measures in $\%$ meter). The different tenor patterns which are combined with these upper voices conform to the same time frame, producing a norm in which the two voices coincide at regular intervals. Departures from this norm produce overlapping of the two voices in the interests of variety. Of most use in explaining this phenomenon, however, are, not the 13th-century treatises on music, but rather those which deal with the new "rhythmic" poetry of the time.
\end{abstract}

\section{Resumen}

El examen de motetes antiguos para dos voces revela el predominio de la línea de siete (u ocho) sílabas en los poemas. Cuando se declaman de la manera habitual, p.e., silábicamente, tanto en el primer como en el segundo modo rítmico, este verso se conforma en un marco temporal de dos dobles longas (o dos compases modernos en compás $\%$ ). Los diferentes patrones de tenor que están combinados con las voces superiores, conforman el mismo marco temporal, produciendo una norma en la que las dos voces coinciden a intervalos regulares. Partiendo de esta norma se produce el paso por encima de las dos voces en interés de la variedad. De más utilidad para explicar este fenómeno, sin embargo, son, no los tratados sobre música del siglo XIII, sino, mejor, aquellos que tratan de la nueva poesía «rítmica» de la época.

Probably the single most popular genre of the later 13th century was the motet. For one thing its various voices represented an intriguing meeting place for the sacred and the profane the sacred in the form of the bottom voice taken from liturgical chant, and the profane as the upper voice or voices which could be devoted to French love songs or criticism of the clergy as well as to sacred Latin poetry. One of its main charms, however, was its flexibility. The texts of its upper voices could be changed, new voices added, different melodies combined, and so on, making it often very difficult to determine an original or authentic version. With secular texts the motet was probably performed for court entertainment, but simply by changing or even omitting the text it could equally well be incorporated into the liturgy. This could occur either with text as a kind of trope, or as an untexted clausula within the longer organa from which the tenor was taken. 
This means, however, that the music itself was basically neutral, it could be performed under a variety of circumstances, depending on the kind of text to which it was joined or even the lack of text altogether. Although, however, text - both of the upper voices and of the tenor fragment - was thus quite literally the determining factor in the performance of these brief pieces, it was conversely the two-voice core of the music (duplum and tenor) which generally remained constant throughout the various different versions. We are thus confronted with dichotomies on various levels when we approach these works. Just how did the two main elements, music and text, interact with each other, and which of the possibilities came first, the texted or untexted, the sacred or secular? We will return to this question a little later.

For the moment we want to concentrate on a specific aspect of these brief pieces, namely on the rhythm which holds their voices together, and its relationship to other phenomena of the 13 th century.

In all of its earlier forms, the lower voice, or tenor, of the motet was taken from specific parts of the liturgical chant. It was not texted, and the tones of the chant were forced, quite arbitrarily, into brief rhythmic patterns of three to seven notes each, which were repeated rigidly throughout the piece. They formed, that is, in a very literal sense, the framework.

The upper voice had its own rhythmic pattern which was longer and was governed by one of only a few possible arrangements of the two basic rhythmic values, the Longa and Brevis, combined in the so-called rhythmic modes. These were named after the antique meters, the most common being trochaic (long-short), iambic (short-long) and dactylic (long-short-short).

Example 1: Modes 1,2,3

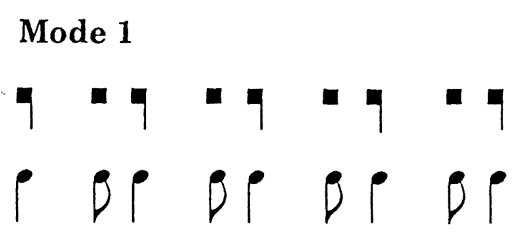

Mode 2

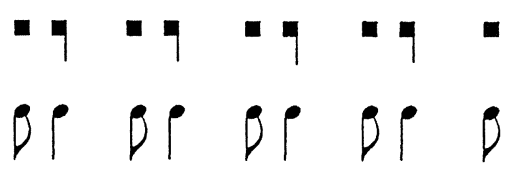

Mode 3

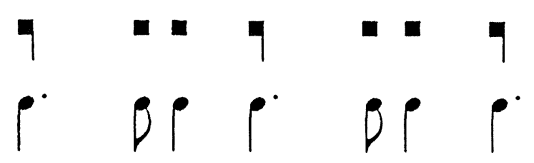

What, however, were the possibilities of fitting together these two very different kinds of voices in the motet, that is, the texted phrases of the upper voice and the rigidly repeating patterns of the untexted lower voice? And where did these patterns come from in the first place? Given the immense number of motets which have survived in collections from the later 13th century, there must have been some kind of norm to regulate their structure, and it is to this question that we wish to turn our attention.

We will begin by examining a few motets which are contained in their simplest, i.e. two-voice version, in the early or Notre Dame manuscripts, including both French and Latin texts. Interestingly, many of them are, however, still transmitted as twovoice motets, now all with French texts, in the much later Montpellier manuscript, the largest single 
collection of motets which has come down to us. ${ }^{1}$ Typically, the upper voices are strictly syllabic in their declamation of the texts, and these, whether Latin or French, are fashioned in poetic lines which rhyme.

Example 2: Hui main-Haec dies
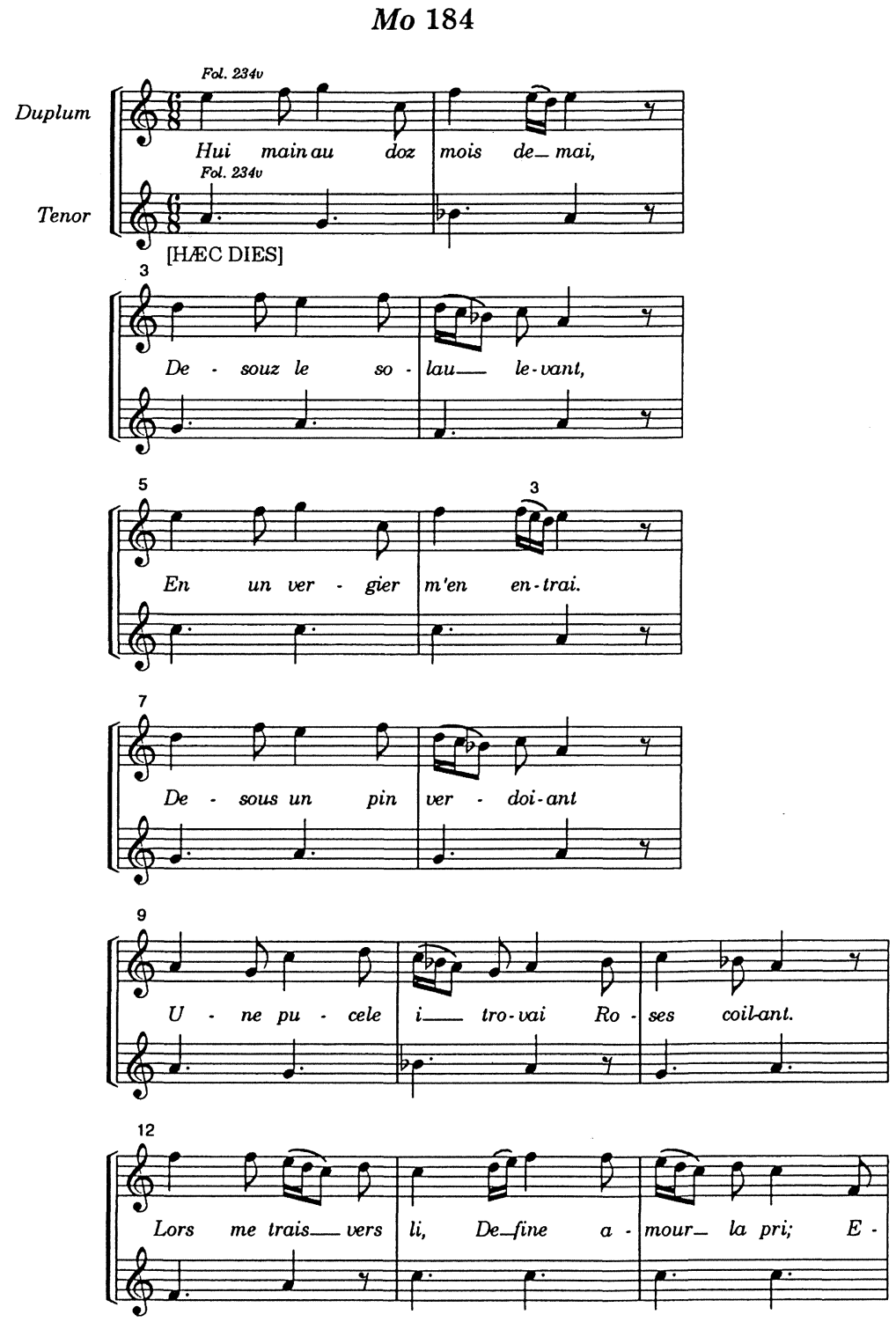

1. Montpellier, Bibl. de l'école de Médecine, H 196 (Mo). Facsimile and edition by Y. Rokseth, Polyphonies du XIIIe Siècle, 4 vols. Paris 1935-39. For a more recent edition see H. Tischler, The Montpellier Codex, 4 vols., Madison, Wisc. 1985. The fourth volume is devoted to translations of the texts by S. Stakel and J. Relihan. 
The tenor of this little piece, the beginning of the Easter gradual, Haec dies, consists of a succession of equal Longs, or the fifth rhythmic mode, divided for the most part by rests into groups of four notes each. ${ }^{2}$ The text of the upper voice, a secular love poem related to the tenor by its beginning words, Hui main, is declaimed in the first rhythmic mode. Its phrases are at first regular, 7-syllable lines, each ending with an accented syllable. These lines coincide each time with four Longs (or two modern measures) in the tenor, forming a kind of regular pattern. When the melody of the tenor repeats, however (5th staff), the upper voice begins to incorporate shorter verses and thus to overlap with the rhythmic units of the tenor, creating phrases of three measures each.

A second example is based on a similar tenor pattern, here, however, divided clearly into 3 equal Longs plus a Long rest, and repeated throughout the piece: ${ }^{3}$

Example 3: Ne sai que je die / Joanne

Mo 185
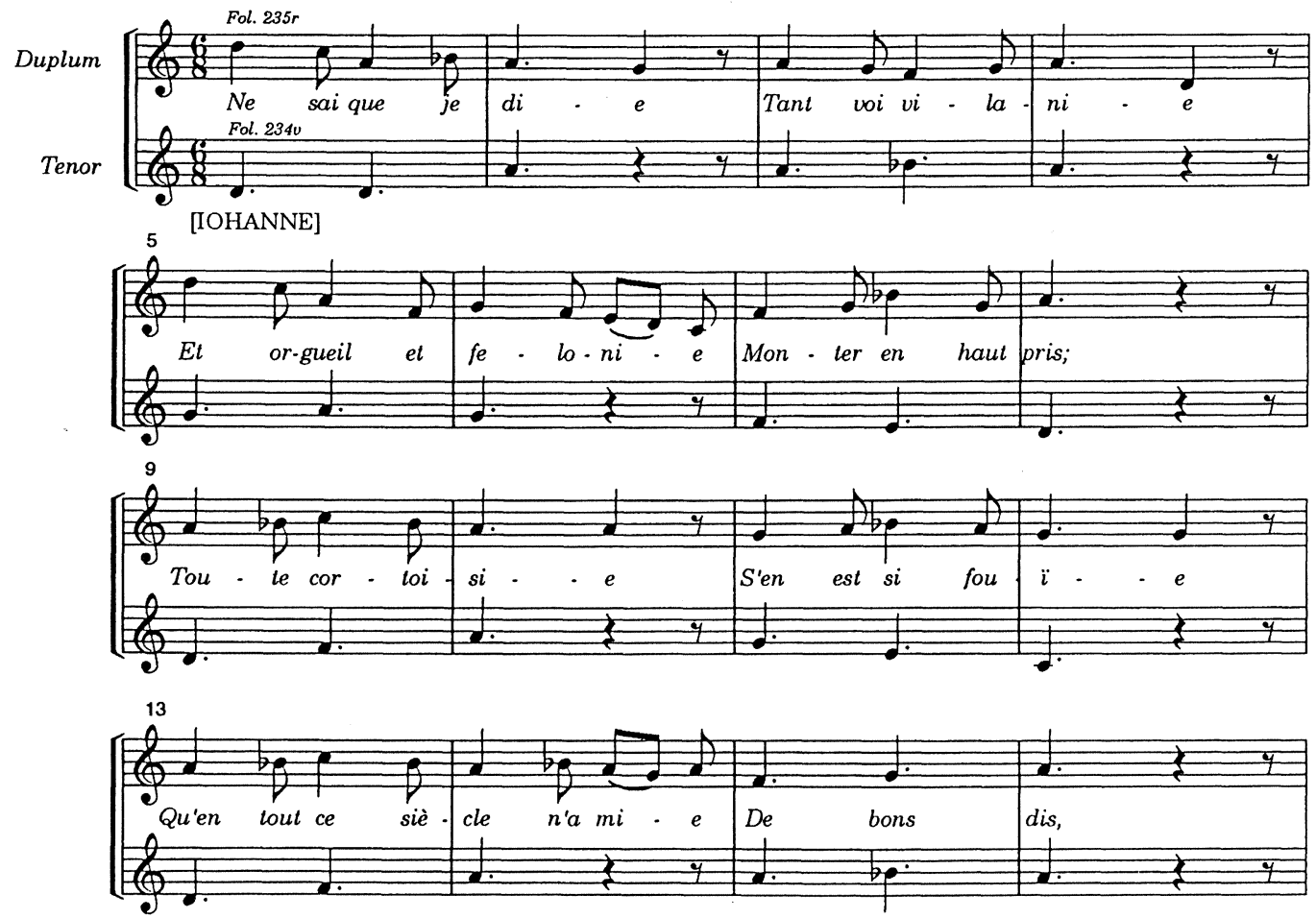

2. This is the arrangement in the Montpellier manuscript. Other sources of the motet, all with the same text in the duplum, have quite different groupings and even different numbers of the tenor Longs. For more information on the many differing versions of the tenor in this motet see M.L. Göllner, "Rhythm and Pattern: The two-voice Motets of Codex Montpellier," Viator 30 (1999), 148-50.

3. The tenor is from the Alleluia for the feast of St. John the Baptist, Inter natos mulierum. 


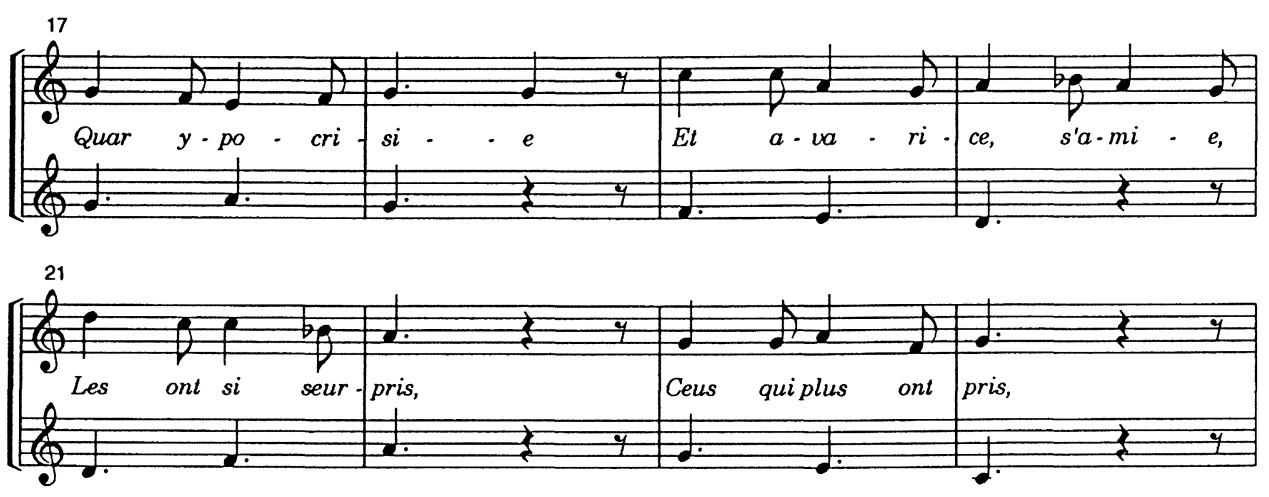

Here we begin with two six-syllable lines in the upper voice, ending with a feminine rhyme; the penultimate syllable is lengthened in the music, and the lines of the upper voice again coincide with the rhythmic units in the tenor.

The next phrase of the upper voice, with the same rhyme, now contains 8 syllables and is followed by a short line of 5 syllables with a new rhyme and a contrasting rising or accented ending. Note that this combination of two lines of different length still fits into the time frame of two tenor units, or four measures, culminating in a Long rest in both voices. In most cases within this piece the lines are in fact paired to correspond to two units of the tenor. A1though the number of syllables in the upper voice continues to vary throughout the rest of the piece, its two rhymes remain the same, and the variations thus fall into a specific pattern: even numbers of syllables —either 6 or 8 - for the spondaic endings (what we would call a feminine rhyme) and odd numbers - 3,5 or 7- for the iambic endings, or masculine rhymes. Most importantly, each line, irrespective of its length, fits into one unit of the tenor pattern, or 3 Longs plus a Long rest.

This particular piece, moreover, has two alternate texts, both Latin, found in other manuscripts. As the example shows, all three of the texts exhibit the same structure as far as the number of syllables in each line is concerned and the same alternation between unaccented and accented endings.

Whereas the first Latin text is very closely related to the French poem in both its rhymes and its content, namely a biting criticism of the clergy, the other is quite different. It alone is directly related to the tenor, for the feast of St. John the Baptist, and can, in fact, function as a kind of trope to it. ${ }^{4}$ Any attempt to establish a chronology, however, proves difficult. Although the French text is found the most frequently, in both two- and three-voice versions, all three are part of the early repertoire. Whereas the structurally more closely related Latin text survived into the famous Roman de Fauvel of the early 14th century, the trope version, which we would tend

4. Since St. John the Baptist was regarded as the model Saint of piety and humility, forswearing the pleasures of this world, the relationship of the first two texts to the tenor is, in contrast, a negative comparison of his virtues to the corruption of contemporary clergy who fall prey to the seven deadly sins. For translations of the texts, both French and Latin, see G. Anderson, The Latin Compositions in Fascicules VII and VIII of the Notre Dame Manuscript Wolfenbüttel Helmstadt 1099 (1206), New York 1972, 376-79. 
Example 4

\section{Mo 185}
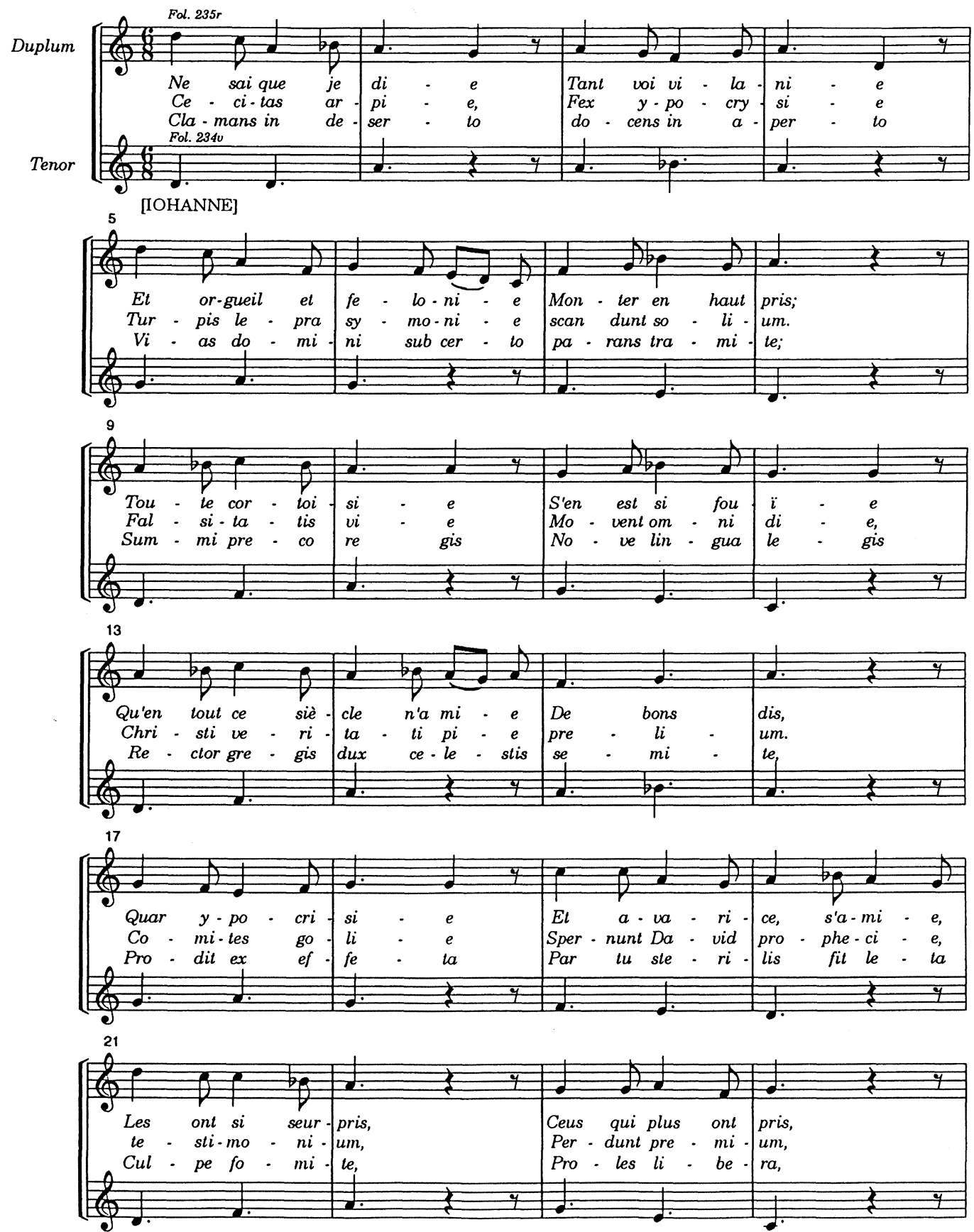
to favor, is found in only one manuscript and may, because of its differing rhymes, actually be the latest of the three. ${ }^{5}$ In this case the music appears almost to have assumed the status of a popular song which stuck in the memory and could be taken over virtually intact to fit various circumstances, both secular and sacred.

In both of the previous examples the upper voice was in the first rhythmic, or trochaic mode (long-short), and the tenor consisted of single Longs. As we can see from the following examples, however, different modes and different patterns operate in a very similar manner.

\section{Example 5: Mo 209: Qui loiaument / Letabitur}

Mo 209
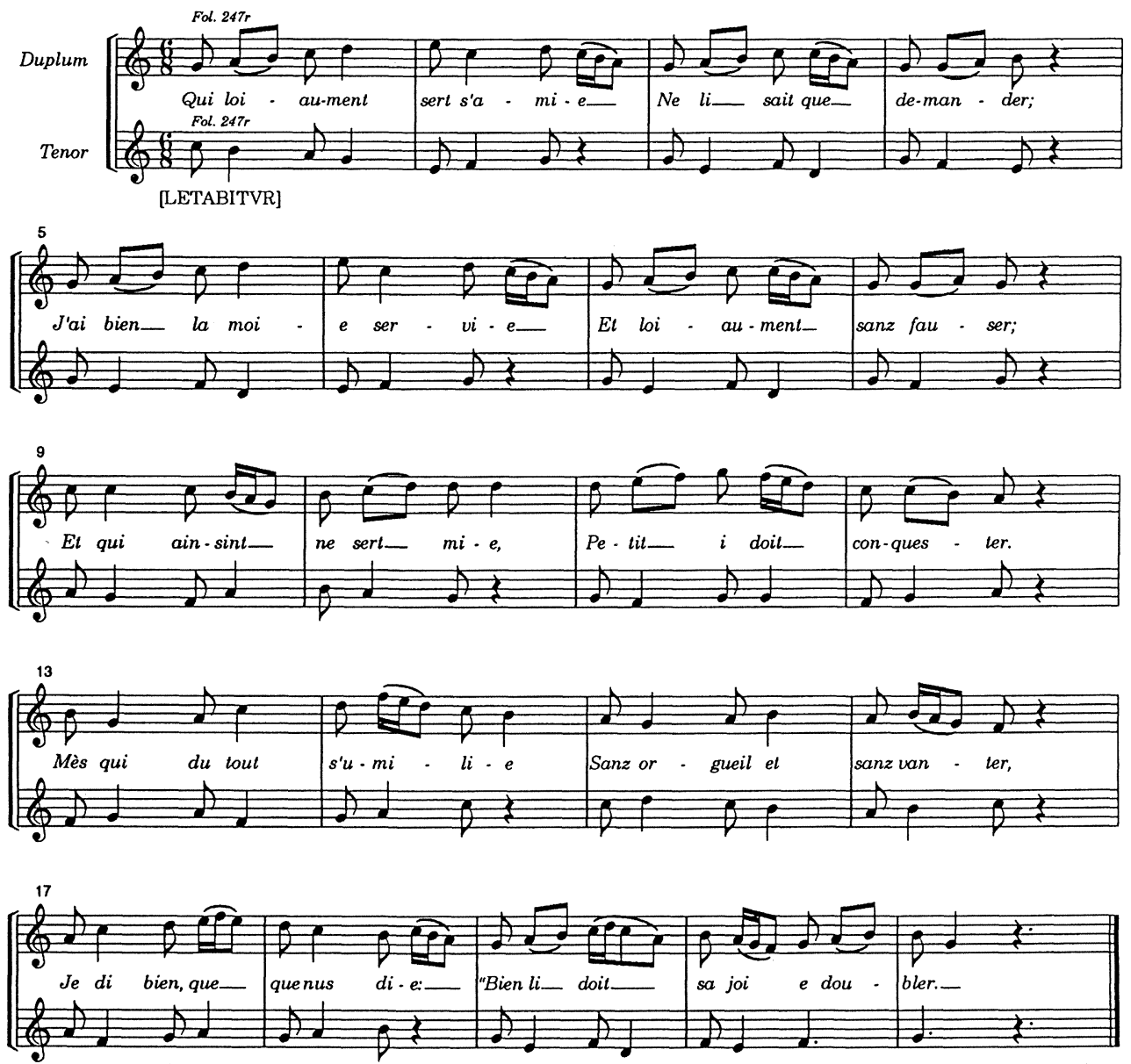

5. Ne sai que je die, Montpellier, f. 235 and W2 (Wolfenbüttel, Herzog August Bibl., Helmstad. 1099) f. 219r/v; Cecitas arpie: W2, f.19lv and Fauvel (Paris, BN, f.fr. 146), f. 13v; Clamans in deserto: F (Florence, Bibl. Med.-Laur., Pluteo 29,1), f. 409v. The French text was also joined to a later triplum, see Anderson, loc. cit. 
Here both voices, the tenor as well as the upper voice, are in the second, or iambic, mode (short-long), which means that the tenor now has more notes and a pattern which is scarcely differentiated from the rhythm of the upper voice. ${ }^{6}$

It still fits, however, into the same time frame, namely two double Longs or two modern measures, and the phrases of the upper voice likewise correspond to these units. Here the lines of poetry alternate consistently between 8 and 7 syllables, again with two- and one-syllable rhymes respectively. In this case, however, the music does not stress the penultimate syllable of the feminine rhymes, but rather keeps the text within the second rhythmic mode in strictly syllabic declamation.

Another motet in the second mode (short-long) has a slightly different pattern in the tenor:

\section{Example 6: Mo 83- En grant esfroi / Mulierum}

\section{Mo 83}

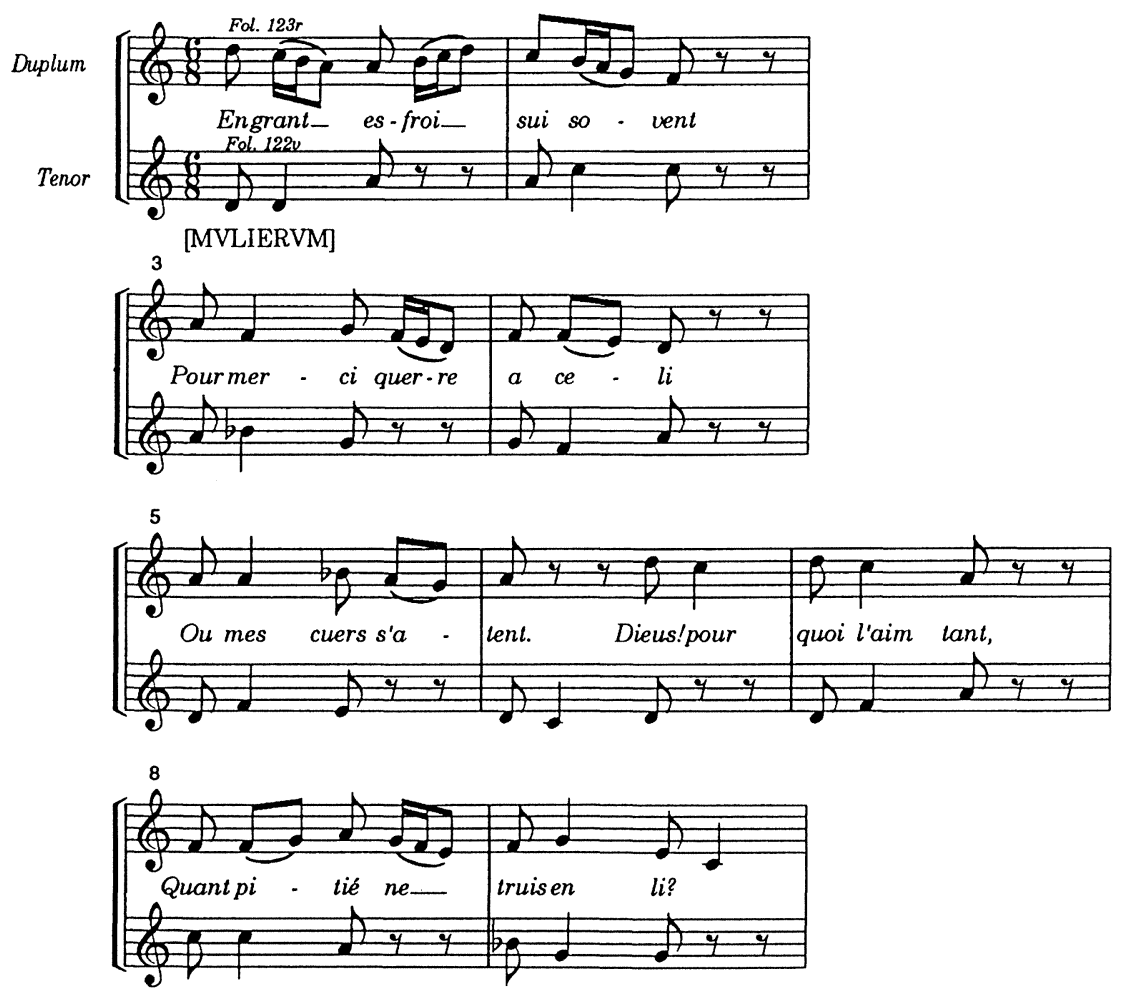

6. $M o$, fol. 247. Although the concordances to this motet, all with the same text, are found exclusively in the older sources, $W 2$ and the two chansonniers, $R$ and $N$ (Paris, BN, f.fr. 844 and 12615), the tenor does not appear to have been taken from the usual liturgical chants and has not to date been identified. See F. Ludwig, Repertorium I/1, 208 and 209 (re W2, 4,10) and H. Van der Werf, Integrated Directory of Organa, Clausulae, and Motets of the Thirteenth Century, Rochester, N.Y. 1989, Mo 209. The secular French text of the upper voice takes up the theme of joy from the surviving word of the tenor fragment, "Letabitur", reflecting on the rewards of serving one's loved one. For a translation see Stakel and Relihan, op. cit. (fn. 1 above), 72. 

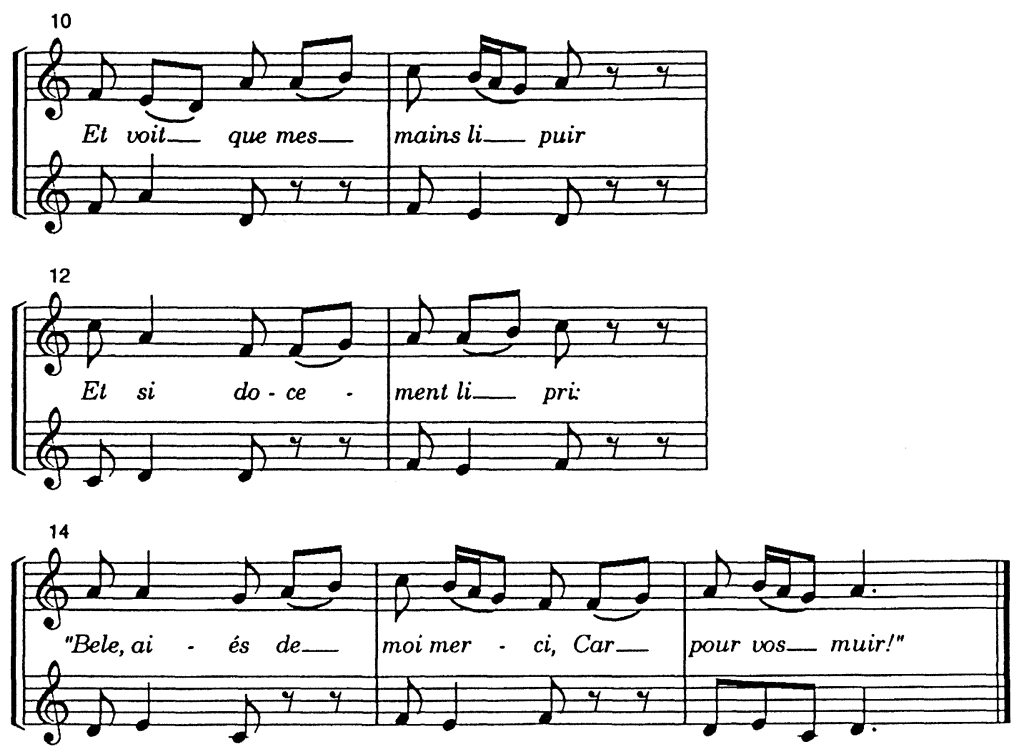

Although the variation in the tenor pattern is minimal, it is more important than it appears at first glance. The substitution of a rest for the fourth note or second Long reduces the pattern from seven notes plus rest, or two double Longs, to two identical units of three notes plus rest, or one double Long which is repeated. And this, in turn, makes possible an interesting variation in the coincidence between the two voices, namely the juxtaposition of two and three units, with one seven-syllable verse for the former and two 5-syllable lines for the latter.

This motet again has many different texts and an added voice in other manuscripts, all, however, consisting of lines which correspond to the same pattern of syllables. The conformity is here so complete that a given text can be sung in either of the upper voices. ${ }^{7}$

\section{Example 7}

Mo 83

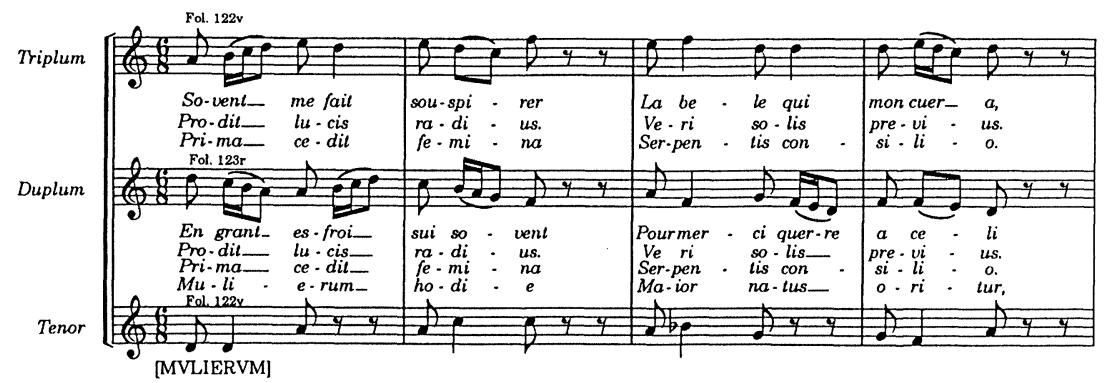

7. The tenor is from the same Alleluia as Mo 83 (see above), but here the texts of the upper voice relate, not to John the Baptist, but rather to the word mulierum, in both its sacred and secular connotations. For translations see G. Anderson, op. cit., 309-11. In the Florence manuscript the motet is contained among the so-called 'conductus motets' of the first motet fascicle, with the same text, Prodit lucis radius, in both voices $(F$, fol. $392 \mathrm{v})$. 


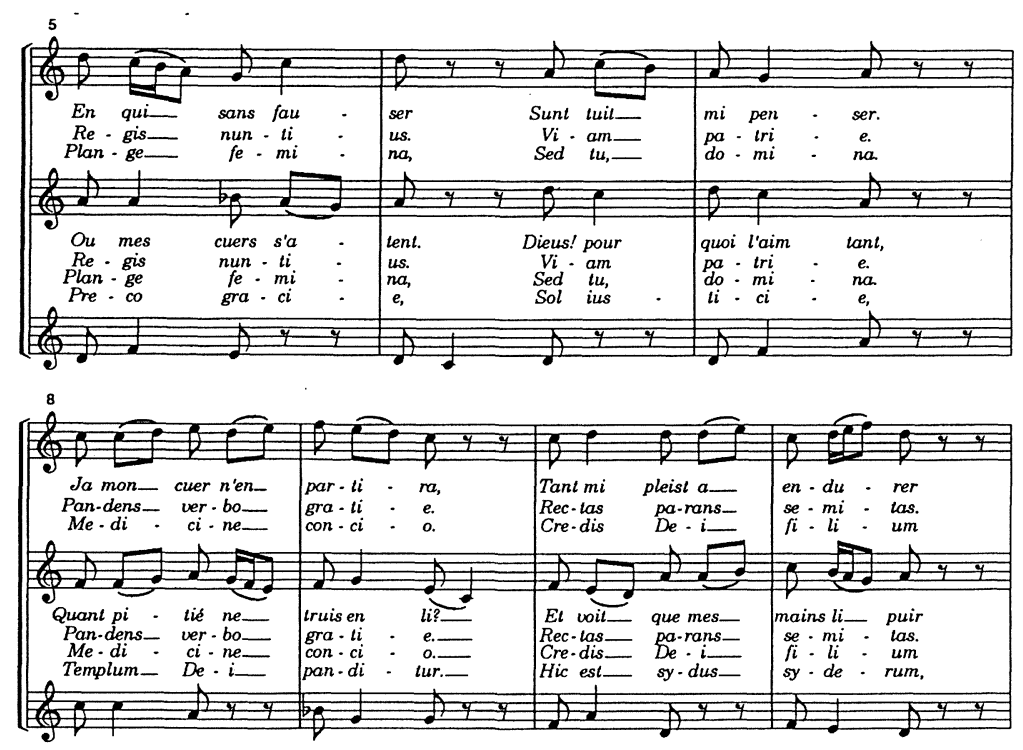

In a final example we see a faster-moving upper voice combined with a tenor which consists of two different parts: the small second-mode unit we have just seen plus two single Longs: ${ }^{8}$

Example 8: Mo 240 Mout soloie / Latus

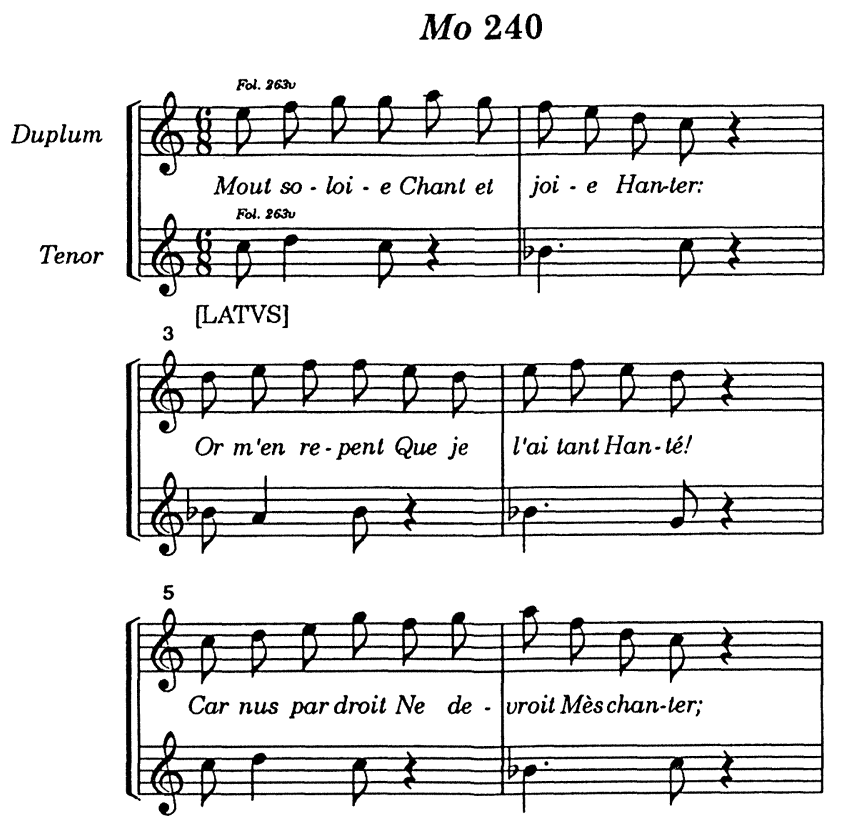

8. Mo, fol. 263v. The tenor is from the Easter Alleluia, Pascha nostrum immoLATUS est Christus. 

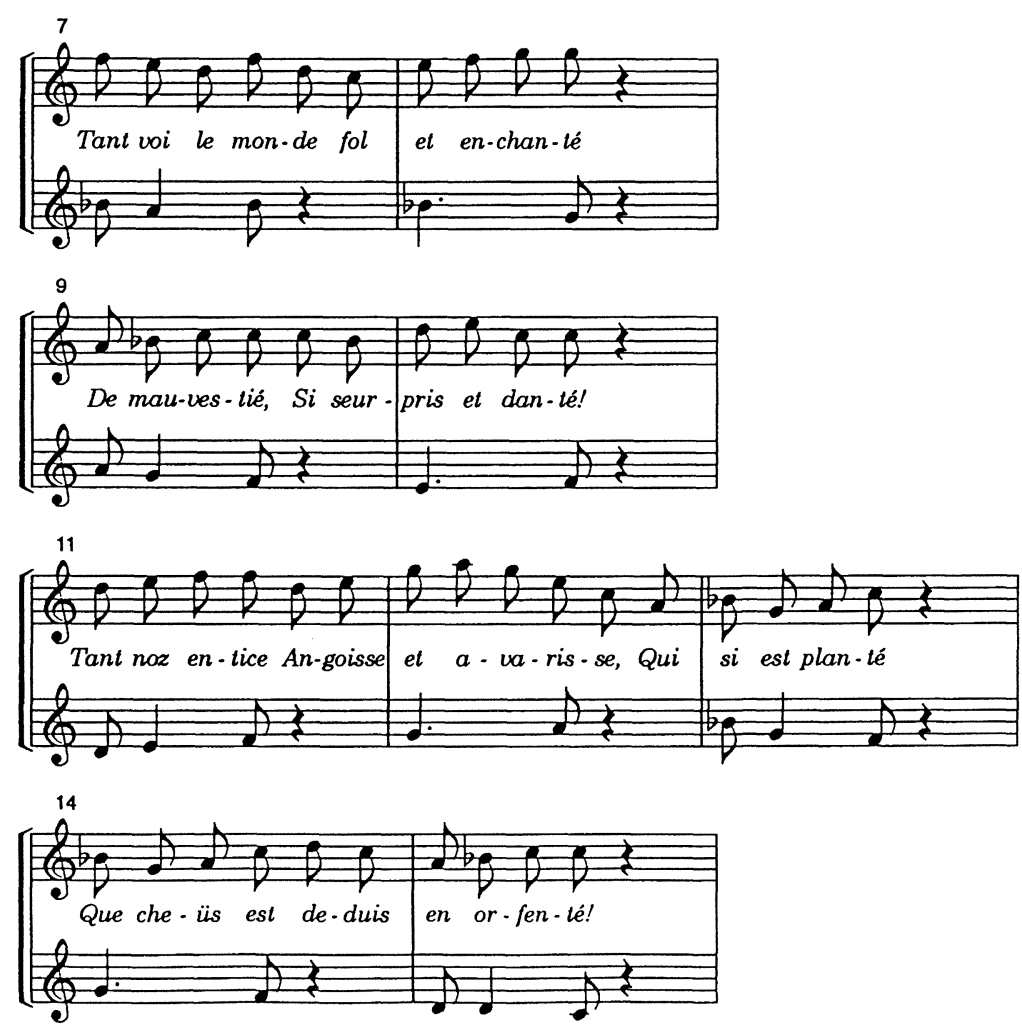

The upper voice now has ten syllables, sung rapidly in even duration, corresponding to the 6th rhythmic mode, and all with iambic, or masculine, endings. Again, the framework, however, remains the same: two modern measures. As the piece progresses, the rigid correspondence between the units of the two voices is somewhat relaxed. Similar to the previous example, unequal lines are combined to form longer units in the upper voice, which then overlap with the tenor. This particular motet, although unique to the Montpellier manuscript in this form, presents a slightly different case from the other examples discussed above. It has, namely, a Latin counterpart text in the older repertoire, ${ }^{9}$ which is directly related to the Easter Alleluia from which the tenor is taken. This text functions clearly as a trope to the tenor, celebrating Christ's victory over death and evil through his resurrection. And here both the particular succession of three- and four-syllable words ("In modulo sonet letitia / Mors moritur oritur gloria") plus the notation of the tenor units as two plus three Longs strongly suggest that this version was written in the third rhythmic mode in the upper voice combined with a tenor consisting of two double plus three single Longs. ${ }^{10}$ The pattern is thus a compound one, and the rhythmic time frame

9. In modulo sonet leticia, $F$, fol. $407 \mathrm{v}$.

10. The same two-voice setting is also found in the Florence manuscript as an untexted clausula on fol. $158 \mathrm{v}$ (Ludwig No. 105), here clearly notated in the ligatures of the third mode. See M.L. Göllner, "The Third Rhythmic Mode in the Thirteenth and Fourteenth Centuries," Revista de Musicologia 16,4 (1993) [Report of the 15th Congress of the IMS, Madrid 1992], 2395-2409. 
becomes double that of the newer version, consisting of eight Longs in two distinct tenor units, still corresponding, however, to the ten-syllable lines of the upper voice. In contrast, that is, to the straightforward correspondence of the seven- or eight-syllable line to its tenor patterns, the ten-syllable verse was allied to either the third or the more modern sixth rhythmic mode, combined with a compound rhythm in the tenor of double and single Longs, or single Longs and second mode respectively.

In this case, then, the history of the piece would be clear: the Latin version would have been the original form, subsequently modernized in both its rhythm and its text for inclusion in the French motet fascicle of Montpellier. Also typical of the later phase, the French text now stands in opposition to the message of the tenor, bemoaning, as in Mo 185 above, the wickedness of the world, here applied to the uncertainty of worldly love.

From these few examples it would, of course, be difficult to draw any firm conclusions. They are, however, very typical of the earliest motets as found both in the Notre Dame manuscripts and in the large sixth fascicle of two-voice French motets in the later Montpellier codex. ${ }^{11}$ As we have seen, two correspondences in particular emerge from the many different rhythmic configurations in both voices: the tenor patterns all tend to fit into the same time frame of four Longs (or this unit doubled), and the most frequently found poetic line of the upper voice is that of 7 syllables with a masculine ending or 8 with a feminine rhyme. The strictly syllabic declamation of one of these lines within either the first or the second rhythmic mode then coincides with one unit of the repeating tenor pattern.

\section{Example 9}
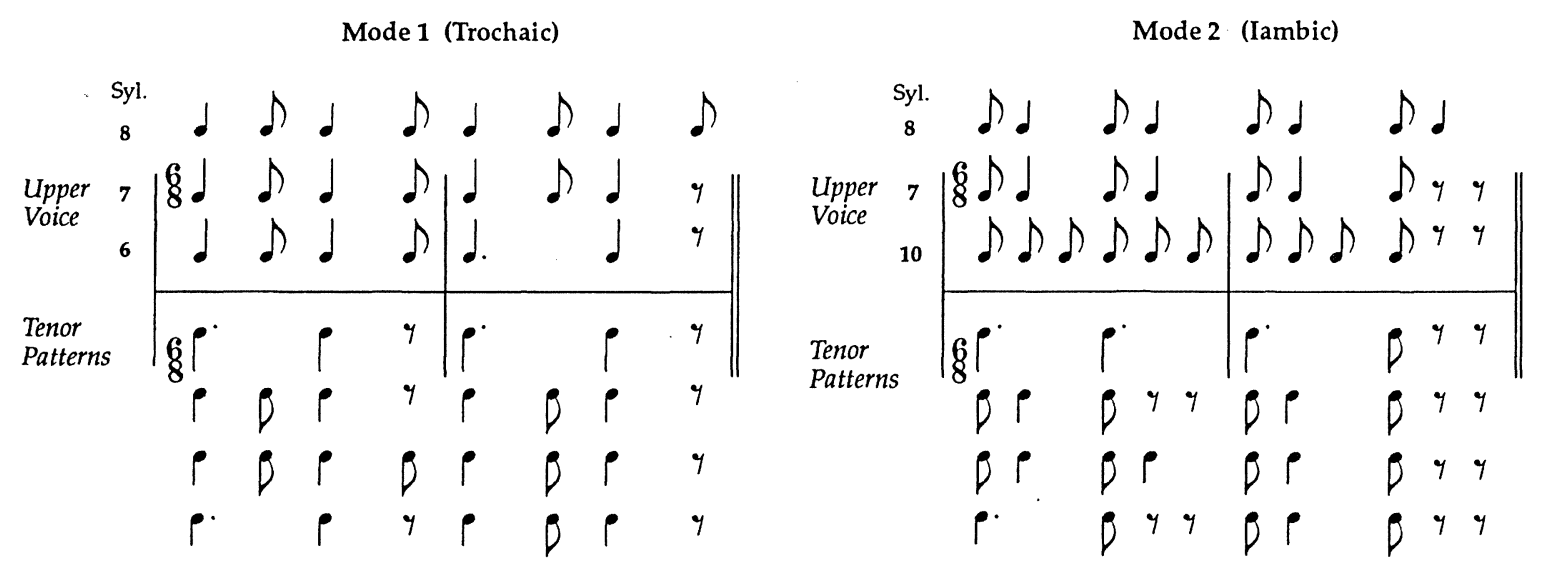

Where, then, can we find any information about this process?

The two main music treatises of the earlier 13th century which talk about rhythm are the anonymous Discantus positio vulgaris and Johannes de Garlandia's De musica mensurabili. They

11. For further examples see M.L. Göllner, "Rhythm and Pattern,”, Viator 30 (1999), 145-63. 
simply list six so-called rhythmic modes, giving them the corresponding names of the Greek meters. Following a favorite topos of the 13th century, the authors then divide these modes into two groups, the simple and the composite, or the brief units of the first, second and sixth modes versus the longer ones of the third, fourth and fifth.

\section{Example 10}

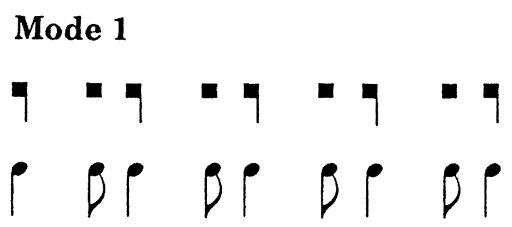

Mode 2

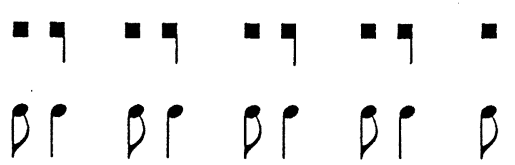

Mode 6

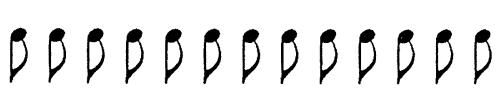

Mode 3

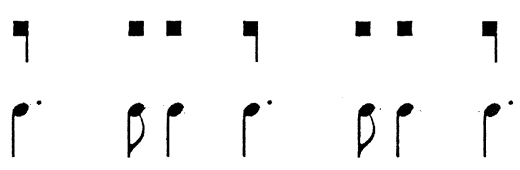

Mode 4

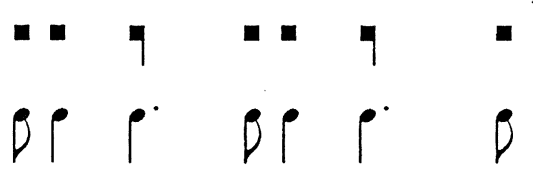

Neither of these treatises however, bothers to explain why the new modes are different from the older meters or how they might have originated. And they take virtually no account at all of rhythmic patterns in the lower voice as found in the motet. Indeed their main concern is not with the motet at all but rather with the untexted discant or rhythmic sections, which are listed by Garlandia as one of the three types of music contained in the long liturgical organa. Having made this distinction, Garlandia then defines discantus in a roundabout way as the "sounding of various different melodies according to mode and the agreement of their values," going on then to describe the six rhythmic modes and their notation in great detail. ${ }^{12}$

In chapter 11 Garlandia returns to this definition as the introduction to a discussion of the different ways in which the rhythmic modes can be combined in two-voice writing. ${ }^{13}$ Here, however, his examples all involve longer passages in two similar voices moving in ordines of irregular length (Reimer I, 74ff). Having finished this discussion, moreover, rather than turning

12. "Sciendum est ergo, quod ipsius organi generaliter accepti tres sunt species, scilicet discantus, copula et organum... Discantus est aliquorum diversorum cantuum sonantia secundum modum et secundum aequipollentis sui aequipollentiam." See the new edition by Erich Reimer, Johannes de Garlandia: De mensurabili musica (Beihefte zum Archiv für Musikwissenschaft, Vol. 10 and 11), Wiesbaden 1972, Part I, 35.

13. The substitution here of the word 'consonantia' for 'sonantia' in some sources and the addition of 'per concordantiam' at the end of the sentence in others are discussed by Reimer in Part II, 24. 
to the motet, he then moves right on to the other two types of two-voice settings, copula and organum (Reimer I, 88ff). The motet is thus never discussed as a separate category. His only mention of it occurs in the first part of the treatise in connection with the fifth rhythmic mode. Whereas this mode will normally, according to his examples, entail undefined numbers of equal Longs, there does exist, he writes, the combination of three Longs followed by a Long rest. This, he continues, "is mentioned here only briefly and not discussed for its own sake, but it is commonly found in this form in the tenors of motets." 14

The very brief anonymous treatise, in contrast, does at least mention the motet specifically as one type of discant with text, differentiating it from conductus and hoquet: "The motet is a song of various lines sounding together over notes of a cantus firmus which are measured or beyond the normal measure and differing from it in both notes and words." 15

Even in the later treatises of the 13th century, motets are consistently regarded, not as a separate category, but rather as one particular type of discant with text. ${ }^{16}$ These treatises, then, are of little help in understanding the fine points of the motet and its composition. For further help let us turn rather to a parallel treatise which can probably also be dated from the first half of the 13th century, this one devoted to poetry and, like the early music treatise, also ascribed to one "Johannes de Garlandia." Although the musicologist, William Waite, considered the two authors to be one and the same person, more recent studies have tended to view them as distinct, both with the same first name and both from the same leftbank part of Paris known as Garlande. ${ }^{17}$ Probably intended as teaching material, the treatises both belong in a larger context. The music treatise on "musica mensurabilis" forms a companion to a similar work on "musica plana" by the same author, and the grammarian's "Ars rhythmica" is one chapter of the famous Parisiana poetria which treats the arts of prose and metric poetry as well. ${ }^{18}$

The chapter on rhythmic poetry can be integrated into a group of writings, also mainly from the 13th century, which attempt to differentiate a new kind of poetry, called "rhythmic", from the older type based on the Greek metric feet. ${ }^{19}$

14. "Alia regula de eodem: tres et tres ligatae cum proprietate et perfectae cum longa pausatione etc., et hoc fit causa brevitatis et non proprie dicitur ita, sed usus est, quod ita in tenoribus motellorum accipiatur, ut hic:" (The example divides the notes of the tenor, Et sperabit, into groups of three Longs plus a Long rest.) Reimer I, 55.

15. "Motetus vero est super determinatas notas firmi cantus mensuratas, sive ultra mensuram, diversus in notis, diversus in prosis multiplex consonans cantus." (CS I, 96).

16. See, for example, Franco of Cologne, Ars cantus mensurabilis (CS I, 130): "Discantus autem aut fit cum littera, aut sine, et cum littera hoc est dupliciter: cum eadem vel cum diversis. Cum eadem littera fit discantus in cantilenis, rondellis et cantu aliquo ecclesiastico. Cum diversis litteris fit discantus, ut in motetis qui habent triplum vel tenorem, quia tenor cuidam littere equipollet." For further discussion of all of these definitions and those of the related categories see H. Tischler, The Style and Evolution of the Earliest Motets (to Circa 1270), IMM 1985, vol. I, 14-20 and 58f.

17. W. Waite, "Johannes de Garlandia, Poet and Musician," Speculum 35 (1960), 179-95. For a thorough discussion of the problem, which concludes that the two authors are separate persons, see the introduction to Vol.I of Reimer's edition, especially pages $12 \mathrm{ff}$.

18. Edited, with an English translation, by Traugott Lawler, The Parisiana Poetria of John of Garland, New Haven and London 1974.

19. Although these treatises were originally edited and discussed as a group at the end of the 19th century by Giovanni Mari, they have, with the single exception of Waite, been given only sketchy attention by music scholars until quite recently. The re-issue of Mari's work by Giovanni Vecchi in 1971 and Lawler's edition of the Parisiana poetria in 1974 finally sparked new interest. For an excellent overview of the entire question and the various editions see Margot Fassler, "Accent, Meter, and Rhythm in Medieval Treatises 'De rithmis'”, Journal of Musicology 5 (1987), 164-190. 
Within this group the relatively late treatise by Garlandia is remarkable, among other things, for its specific reference to music - "Ars rhythmica est species artis musice" - and for its use of basic terms also familiar from music treatises, such as "Clausula" for strophe, or "Consonantia" for rhymed endings. There are, however, several other important points to which I want to call attention. First of all, in contrast to the music treatises, this author is specifically concerned with pointing out the differences between the new kind of "rhythmic" poetry and the older "metrical" poetry. This has several important consequences: first, he recognizes the problem of retaining the Greek names from the latter, but does not succeed in inventing a new, more appropriate terminology. He is thus obliged to skirt the issue by speaking of combinations of long and short values as "quasi metrum" or "cum rithmus imitetur metrum". Further, like other treatises of the group, he relies initially on the line endings as determinants of rhythmic identity and reduces the number of combinations to only two, namely the iambic and the spondaic, i.e. a rhyme whose final syllables are either short-long or both long (from his examples we would often consider the latter trochaic). His definition of "rithmus" is then:

"Rithmus est consonancia dictionum in fine similium, sub certo numero sine metricis pedibus ordinata," that is, the rhythmic line is determined not by metrical feet but rather by the nature of its end-rhyme and also by the number of syllables it contains. Particularly this last criterium, the number of individual syllables, represents an entirely new concept in the fashioning of poetic lines, and it is this feature to which we will return.

This author also introduces, however, another term and its concept which are strangely missing from music treatises, even though they would seem to be more appropriate there, namely the idea of accent, expressed here by the word, "percussio". This term, to be sure, has its own tradition in both kinds of treatises, the literary and the musical, but with a different meaning in each case, i.e. accent or beat when poetry is read aloud versus the production of sound as "beats of air" in music, and these two strands appear still to run separately in the early 13 th century. ${ }^{20}$

A line of a rhythmic poem, then, is characterized by a) its rhyme, b) the number of syllables which it contains, and c) by the number of accents and their placement within it. After the usual listing of all possible combinations, the author makes a further familiar distinction, namely that between simple and composite strophes of a rhythmic poem, i.e. between those which consist entirely of either "iambic" or "spondaic" lines and those which contain a mixture of both types. This second type, which he recommends as particularly interesting, entails, in turn, an alternation not only in the rhyme but also in the number of syllables to produce endings which are either on accented or unaccented syllables. To use his examples: ${ }^{21}$

20. For a brief overview of the use of the term in its literary context see Charles M. Atkinson, "Franco of Cologne on the rhythm of organum purum," Early Music History 9 (1990), 16ff. On the musical side the definition for "sonus" provided by Boethius in his De institutione musica persisted throughout the Middle Ages: "Idcirco definitur sonus: percussio aeris indissoluta usque ad auditum." Fassler, op. cit., 188ff, suggests an intriguing relationship between word accent, polyphony and the origin of the rhythmic modes.

21. Lawler, op. cit., 164. 
Pulcra casta Katerina, Flos et gemma Grecie, Sub scolari disciplina Donum sumpsit gratie.

that is, an alternation between spondaic and iambic, i.e. falling and rising endings, or eight- and seven-syllable lines. If, on the other hand, the iambic line should precede, this can be accomplished simply by retaining it in the same form but dropping two syllables from the, now second, spondaic line and thus alternating between seven and six syllables:

Flos et gemma Grecie,

Casta Katerina

Donum sumpsit gratie,

Tendens ad divina.

Although most of the recent scholars who have dealt with this treatise have, in fact, applied its remarks to poetry and the questions this raises for medieval Latin monophony, such as the sequence, my own investigation concerns that category which definitely operated within the confines of rhythmic pattern, namely the motet. ${ }^{22}$ And, as we can see, Garlandia recommends exactly those poetic lines and their kind of rhyme which occur most frequently in the early motets. Although the author of the treatise deals only with Latin poetry, he does refer several times to its vulgar, or French, counterpart as well. And since Latin and French texts could be substituted for each other at will in the early motet, it is clear that, here at least, both kinds of poetry operated under identical principles.

In summary, then, I would like to suggest the following:

1) There did exist a norm in the composition of motets.

2) This norm can be observed most clearly in the identical time frame of the various different tenor patterns as found in the early repertoire. This unit is not of strictly musical origin, however, but is derived from the most frequently found verse line, namely that of seven or eight syllables with iambic or spondaic endings respectively. When declaimed syllabically in either the first or second rhythmic mode, these lines coincide with two double longs, as do the various tenor patterns.

22. Fassler, op. cit.,188f, explores the influence of polyphonic music on monophonic rhythm in the later 13 th century (sequence and conductus), and John Stevens, Words and Music in the Middle Ages, Cambridge 1986, 416ff, emphasizes the importance of syllable-counting in the new "rhythmic" poetry and the unity of music and poetry as sound ("non-liturgical" song, both Latin and French). Both conclude that the treatises imply equal duration of the syllables. For a discussion of the motet in the context of this new poetry see M.L. Göllner, "Musical and Poetic Rhythm in the 13th Century," Anuario musical 45 (1990), 1-16. 
Mode 1 (Trochaic)

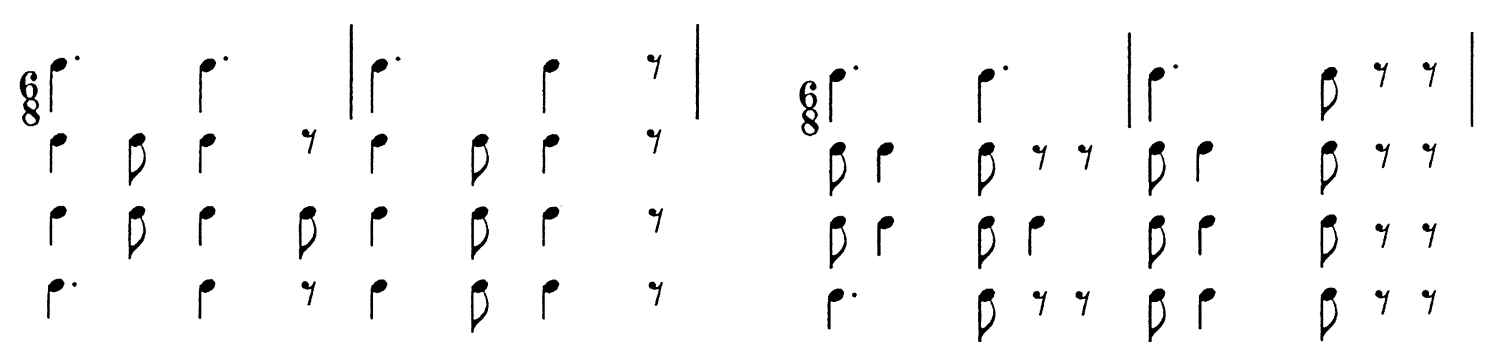

3) The poetic lines fit the descriptions provided by the treatise on "rhythmic poetry" by Johannes de Garlandia, and these rules apply to French as well as to Latin texts, enabling the two languages to be interchanged.

4) The poetic treatise is consequently of more use to us in understanding the motet than are the music treatises of the same time which deal mainly with organum and discant and their notation.

5) The 10-syllable line was probably originally allied with Latin texts and the third rhythmic mode over a composite tenor which occupied a double time frame. In French this line could also be fitted into the same tenor time frame as the first and second modes by using the rapidly declaimed equal breves of the sixth mode in the upper voice in combination with the second mode in the tenor.

The later motet became more intricate in a variety of ways. Musicians and poets were able to bring more and more variety into their works by combining lines or changing the number of syllables in the lines of the upper voice so that they overlapped with the units of the tenor. The individuality of each motet was thus substantially increased. In addition, the units of the tenor itself could be changed, abbreviated, for example to three Long values, which then coincided with five-syllable lines in the upper voices but automatically overlapped with the usual seven and eight syllables. ${ }^{23}$

23. These patterns can be found fairly frequently in both two- and three-voice motets, some of them in the earlier sources as well. See Mo 187 and $210(2-v$,$) or 45, 81$ and 82 (3-v.). In many cases, particularly in the two-voice motets, the voices then coincide at regular intervals, e.g. after every two seven-syllable lines (Mo 210). 
Example 12

5

$13 d$
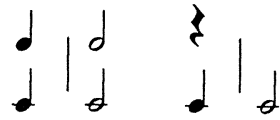

$+1$

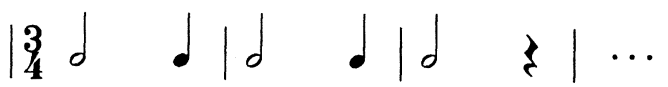

$13 d d|d d| d \&$

$|3 d+1 d| d \mid \cdots$

When a third voice was added, the possibilities were enormously expanded. With increasing proficiency in the techniques of composition came the desire to explore new ways of combining the voices, a desire which is reflected in both formal and expressive ways. The possibilities range from the exact correspondence of the voices, as in example 7 above, through continuous overlapping in all

voices. Perhaps more common than either of these solutions, however, i.e. consistent correspondence or consistent overlapping, is the practice of beginning with matching phrases of seven or eight syllables and then departing from this scheme in one or both voices as the motet progresses. In the older repertoire a typical method involved coupling the two upper voices while changing their relationship to the tenor. ${ }^{24}$

In the later repertoire all three voices are often involved.

\section{Example 13, Mo 85}

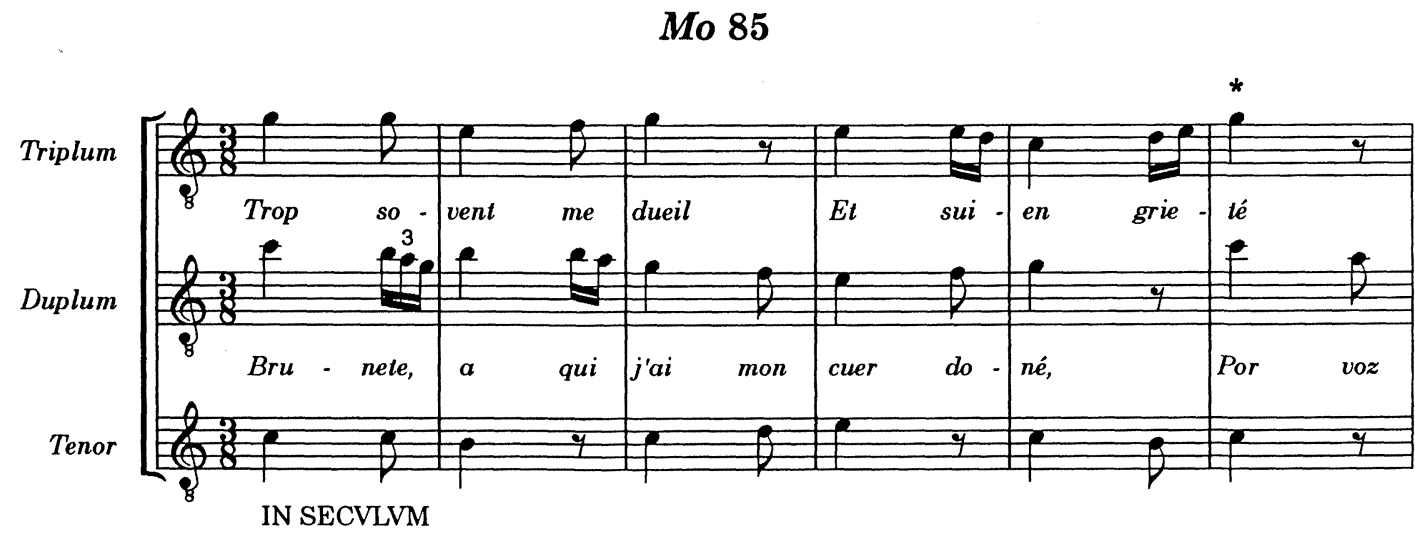

24. More of these have survived into the late three-voice fascicles of the Montpellier manuscript than one might expect. See, for example, Mo 43 (and 141), where the French text, Quant voi l'erbe, is combined with the music of the triplum in one version and with that of the duplum in the other; Mo 116, where both upper voices change from seven- to ten-syllable lines when the tenor repeats with a different rhythm and then back again; Mo 132, with alternating seven- and eight-syllable lines; Mo 45, with alternating seven- and five-syllable lines over an abbreviated tenor, and so on. 

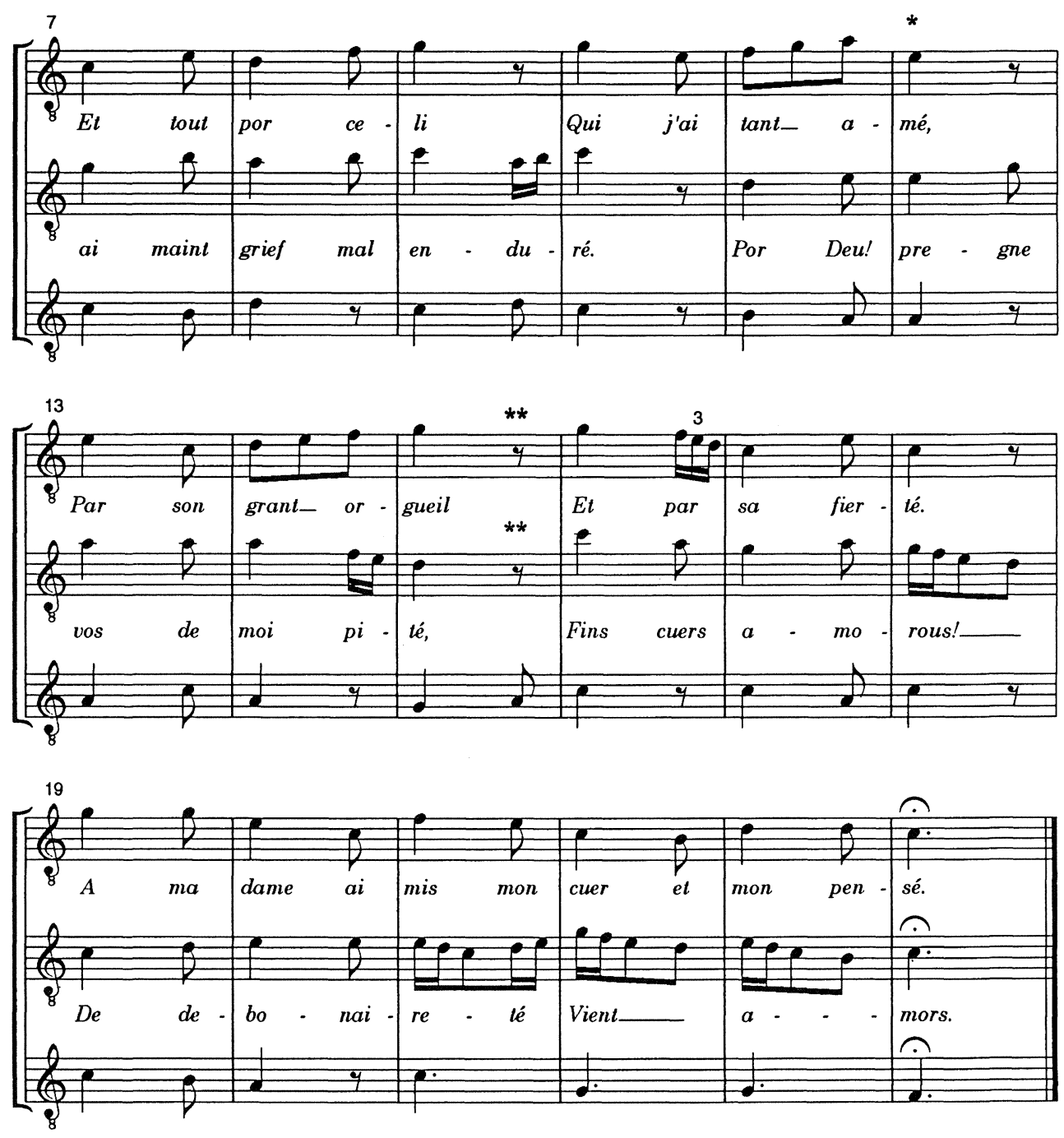

This brief little motet is based on a further segment from the Easter Gradual, Haec dies, as tenor. ${ }^{25}$ Here each of the upper voices has its own scheme, of five- and nine-syllable lines respectively, and all parts overlap. A repeating tenor unit of two Longs (i.e. 2 measures in $3 / 8$ time) is combined with a triplum of three- and a duplum of five-measure phrases. Whereas two lines of the triplum coincide regularly with three tenor units (m. 6, 12 and 18; see also example 6 above), the longer phrases of the duplum meet the tenor only at the end of its second line in $\mathrm{m}$. $10(2 \times 5=5 \times 2)$ and the triplum only at m. $15(3 \times 5$ measures of the duplum $=5 \times 3$ measures of the triplum). At this point the duplum joins the triplum with an added five-syllable line,

25. $M o$, fol. $124 \mathrm{v}-125$. For more information about other sources of this motet and about its refrains see Ludwig, Repertorium, 366. 
bringing all three voices together for the first time at $\mathrm{m}$. 18. The end of the motet is then obliged to resort to irregularities in all of the voices, including the tenor, in order to accommodate the concluding refrains of the upper voices.

In three-voice motets, particularly the later ones, the emphasis was likewise increased on subtle interactions of meaning and content among the various texts, i.e. a layering of meanings as well as of rhythmic units. ${ }^{26}$

Ultimately, the tenor patterns were extended into longer irregular units, prefiguring the isorhythmic motet.

In conclusion, I would like to offer just a few thoughts on the relationship between motet and clausula as suggestions for further contemplation:

1) That the untexted clausula did, as assumed by most scholars, ${ }^{27}$ come first historically, and that it consisted at first of longer, unregulated phrases in both voices, similar to those found in the music treatise of Johannes de Garlandia and also in many of the clausulae contained within the organa of the notre Dame manuscripts.

Example 14: Johannes from F, fol. 121

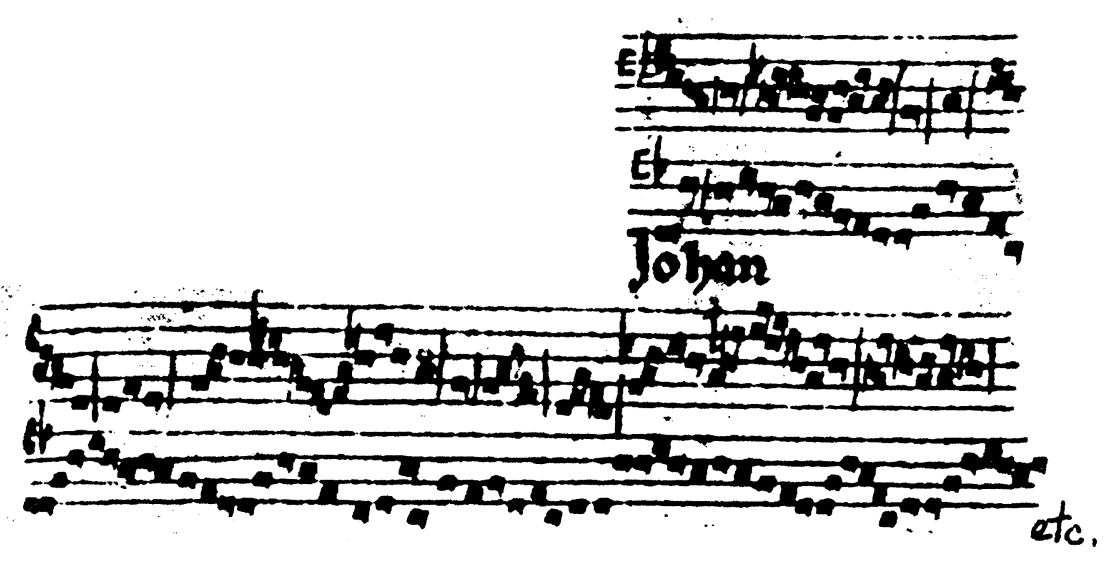

2) That the clausulae transmitted in groups as found in the Florence manuscript, on the other hand, reflect the decisive influence of the motet, and thus of poetry, in combining the notes of the tenor into strictly regulated patterns which correspond to the phrases of the upper voice in the manner we have observed. This does not mean that these clausulae must all be viewed as textless reductions of specific motets, but rather that they adopted the principles which had been developed through poetry for the motet. The rather large number of them in the Florence manuscript which have no corresponding motets may well be an indication that they constituted a kind of miniature exercise in composition, now independent of any specific text.

26. For an intriguing account of these interactions and their relationship to the other literature of the period see the recent book by Sylvia Huot, Allegorical Play in the Old French Motet, Stanford, Calif. 1997.

27. See H. Tischler, The Style and Evolution of the Earliest Motets, Vol. I, Ch. 3, $21 \mathrm{ff}$. 
3) That the early two-voice motet reflects very clearly the principle of alternation and juxtaposition, as found in the poetic treatises. There it concerned rhymes and number of syllables. In music it is applied to units of time, particularly between those of two and three, i.e. the rhythmic modes of the upper voices which were determined by triple rhythm against the larger duple units of the tenor; or the alternation between phrases of two and three double Longs each. In the 14th century this kind of layering in two versus three became a dominant principle in the music and its notation.

4) That the related topos of simple versus composite, found in the treatises, likewise forms a basic tenet of the motet: the simple modes of the upper voice against the usually compound patterns of the tenor. And this same principle can be found in the articulation of the nave in the Gothic cathedrals of the 13 th century. 


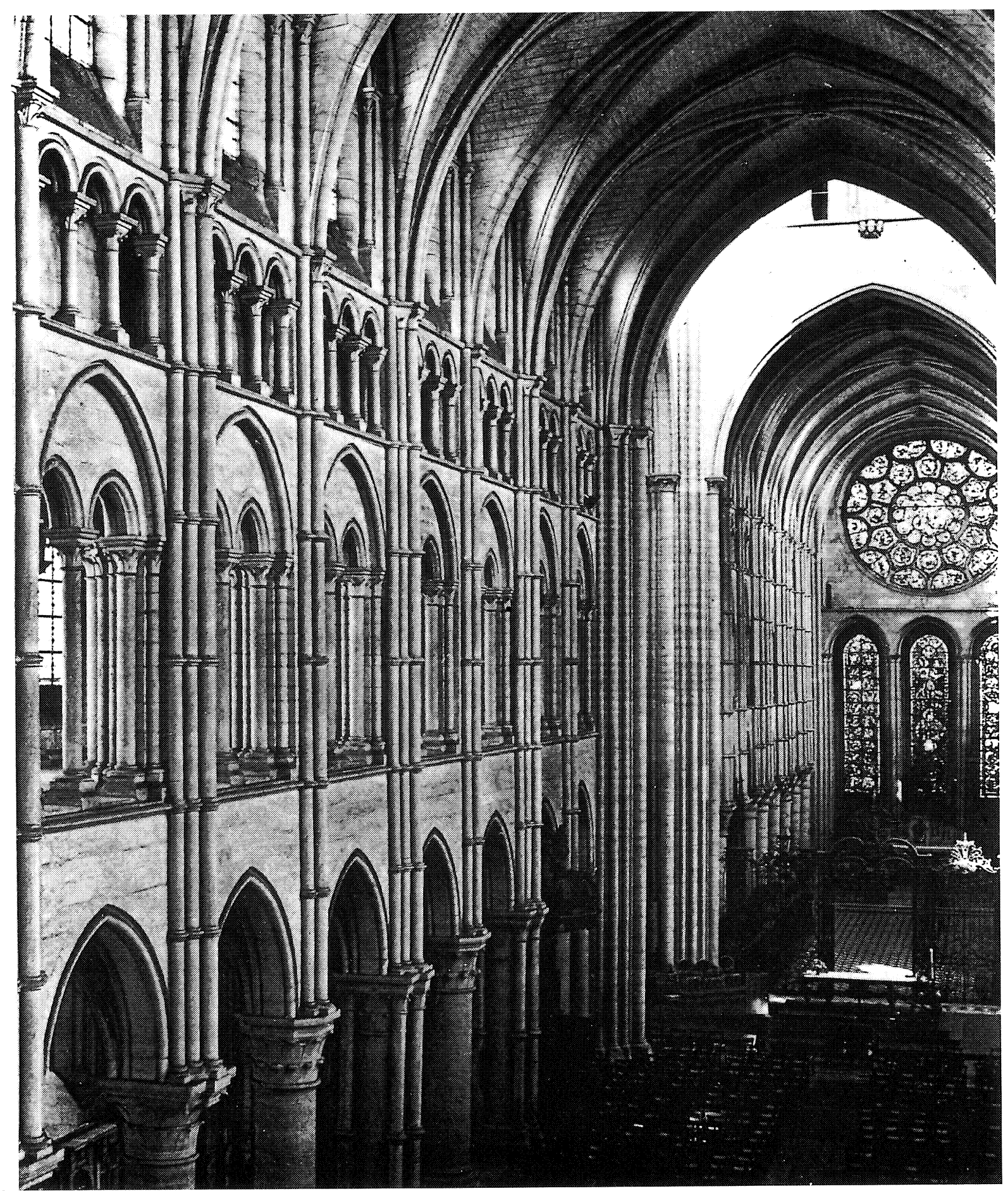

Example 15: Laon Cathedral 